\title{
First observation of fouling of externally attached radio transmitters in an African river
}

\author{
Francois Jakob Jacobs ${ }^{1,6}$, Olaf Lawrence Friedrich Weyl2 ${ }^{2}$ Eva Marita Ulvan ${ }^{3}$, Clinton Hay ${ }^{4,5}$ and Tor Fredrik Naesje ${ }^{3,6}$ \\ ${ }^{1}$ Ministry of Fisheries and Marine Resources, Private Bag 5147, Kamutjonga Inland Fisheries Institute, Divundu, Namibia \\ ${ }^{2} D S I / N R F$ Research Chair for Inland Fisheries and Freshwater Ecology, South African Institute for Aquatic Biodiversity, \\ Private Bag 1015, Makhanda 6140, South Africa \\ ${ }^{3}$ Norwegian Institute for Nature Research (NINA), PO Box 5685 Torgarden, NO-7485 Trondheim, Norway \\ ${ }^{4}$ University of Namibia, Private Bag 13301, Windhoek, Namibia \\ ${ }^{5}$ Namibia Nature Foundation, PO Box 245, Windhoek, Namibia \\ ${ }^{6}$ South African Institute for Aquatic Biodiversity, Private Bag 1015, Makhanda 6140, South Africa
}

Fouling of externally attached tags is an important consideration in long-term tagging studies as it may affect fish behaviour and well-being. Two externally attached radio transmitters on African tigerfish Hydrocynus vittatus were covered with short green algae, after the fish were recaptured 49 and 64 days after tagging in the Kavango River, Namibia. This is the first observation of fouling on external radio transmitters from any African river which highlights the importance of conducting studies that evaluate the various health or behavioural effects resulting from tagging.

\section{INTRODUCTION}

Electronic tagging and tracking of fishes (i.e. telemetry) can provide valuable information on the spatial ecology, migration and response to environmental changes, making it one of the preferred methods to study freshwater fishes worldwide (Thorstad et al., 2013; Jepsen et al., 2015). External transmitters are commonly used in telemetry studies; however, tissue damage, reduced growth, increased mortality and decreased swimming performance are associated potential negative effects (Jepsen et al., 2015). Externally attached transmitters change the stream-line body shape of fishes, and reduced swimming performance from additional drag has been experimentally demonstrated for relatively small (120-200 mm in length) Atlantic salmon Salmo salar smolts (McCleave and Stred, 1975; Moore et al., 1990), juvenile rainbow trout Oncorhynchus mykiss (Mellas and Haynes, 1985) and juvenile white sturgeon Acipenser transmontanus (Counihan and Frost, 1999). In adult S. salar, however, Thorstad et al. (2000) reported no difference in swimming performance between fish with externally attached transmitters vs. untagged controls. Interestingly, during a different study by Thorstad et al. (2001) the relatively poor condition factor of an adult farmed S. salar fitted with an externally attached transmitter was attributed to additional drag resulting from transmitter fouling with green algae, mussels, seaweed and Balanus sp.

In southern Africa, external radio tags to monitor freshwater fish movement behaviour are increasingly being used in a range of environmental monitoring, conservation and research programmes (O'Brien et al., 2012; O’Brien et al., 2013; Burnett et al., 2018; Roux et al., 2018; Burnett et al., 2020). External radio tags are generally preferred over surgically implanted transmitters as the latter have been shown to cause $100 \%$ mortality or tag loss in a Namibian reservoir (Økland et al., 2003). To date, however, there have been no studies on the possible effects of external radio transmitters, nor has there been a recapture of any radio-tagged fish (Eva et al., 2005; Økland et al., 2005; Thorstad et al., 2005; O'Brien et al., 2012; O’Brien et al., 2013; Jacobs et al., 2016; Burnett et al., 2018; Roux et al., 2018; Burnett et al., 2020) that could provide evidence of potential negative effects of using this method.

Here we report on the first observed fouling of external transmitters attached to African tigerfish Hydrocynus vittatus, Castelnau 1861, in the Kavango River, Namibia. These fish were part of a larger study involving the movement behaviour of 49 tigerfish (Jacobs et al., 2020). The standardized tagging procedures were as follows: Tigerfish were anaesthetized using 2-phenoxy-ethanol $(0.3 \mathrm{~mL} / \mathrm{L})$ and fitted with external radio transmitters (Model F2120 Advanced Telemetry Systems, Inc., Isanti, MN, USA) that are encapsulated in $3 \mathrm{M}$ Scotchcast and the antenna was nylon coated, weigh $16 \mathrm{~g}$ in the air and measure $55 \times 20 \times 11 \mathrm{~mm}$. Transmitters were attached with orthopaedic wire $(0.65 \mathrm{~mm}$ diameter $)$, threaded horizontally through the pterygiophore bones in the dorsal musculature. The external transmitters were secured by twisting and locking the ends of the wire against a flat plastic back-plate on the opposite side of the transmitter. The tags were attached tightly to the body of the tigerfish to minimize the risk of snagging or fouling, and to minimize possible drag. After tagging, fork length $\left(L_{F}\right)$ was measured to the nearest $\mathrm{mm}$ and total body mass $(\mathrm{g})$ recorded, and all fish were released at their capture site.

Two tigerfish, with $L_{F} 510 \mathrm{~mm}$ and $588 \mathrm{~mm}$, and weight $2800 \mathrm{~g}$ and $3530 \mathrm{~g}$, were recaptured by anglers, 49 and 64 days after being radio-tagged. The first tigerfish was recaptured in the Mahangu Game Park by angling scientists $6.34 \mathrm{~km}$ downstream from its tagging location. At recapture, the tigerfish measured $L_{F} 515 \mathrm{~mm}$ and weighed $2890 \mathrm{~g}$. The second tigerfish was recaptured $80.6 \mathrm{~km}$ downstream from the tagging location by a professional angling guide in the Okavango Panhandle, Botswana.
CORRESPONDENCE

Francois Jacobs

EMAIL

Francois.Jacobs@mfmr.gov.na

\section{DATES}

Received: 9 March 2020

Accepted: 16 October 2020

\section{KEYWORDS}

freshwater

fouling

Kavango River

tagging

tigerfish

Namibia

\section{COPYRIGHT}

() The Author(s)

Published under a Creative

Commons Attribution 4.0

International Licence

(CC BY 4.0) 
No physical measurements were recorded for the second recaptured tigerfish and information regarding the growth on the tag was based on a verbal report from the angler. In both cases, however, the transmitter, antenna, attachment wire and plastic back-plate were overgrown by green algae (Fig. 1). In addition, both tigerfish had signs of some dermal abrasion, approximately one scale row below the position of the transmitters (Fig. 2). Although no clear infection was observed, redness of the dermis probably resulted from irritation between the transmitter and the dermis, which can be expected with externally attached transmitters (Herke and Moring, 1999). The second recaptured tigerfish increased in length and weight over the study period, which suggests that the general health of the fish was not noticeably negatively influenced by the tag.

This is the first documented observation of fouling of externally attached radio transmitters in any African freshwater river. Although reduced swimming performance from additional drag has been experimentally demonstrated for juvenile and small fish species, we were studying adult specimens (Jacobs et al., 2020). Based on the survival and growth demonstrated by one fish, the distances travelled and the fact that the transmitter weight combined with additional weight from algal fouling remained far less than the recommended $2 \%$ tag weight to body weight 'rule' (Winter et al., 1996), we conclude that the observed growth on the transmitter may not have significantly influenced adult tigerfish behaviour. This suggests that this approach is suitable for behavioural ecology experiments on tigerfish. In severe cases irritation may lead to infections that could result in mortality of the tagged fish (Økland et al., 2003). As a result, alternative attachment methods such as the silicone-mound method (Crook, 2004) that has been used successfully on golden perch Macquaria ambigua and common carp Cyprinus carpio could be evaluated. Although the weight of the fouled tag was less than $2 \%$ of body weight, external tags can impart additional drag and the use of internal radio transmitters could be considered in future studies. Antifouling paints on the exterior surface of transmitters are common in marine telemetry studies and may be advantageous to reduce fouling (Balmer et al., 2011); however, caution must be taken to ensure that the chemicals utilized in anti-fouling paints do not have negative effects on the tagged fishes. Baras et al. (2002) reported no negative effects from internal tagging of tigerfish over a one-month period and the application of this method may be explored.

While the observed fouling was less severe than the green algae, mussel, seaweed and Balanus sp. fouled tags reported to influence S. salar behaviour (Thorstad et al., 2001), our observations nevertheless suggest that tag fouling and its potential effects on the behaviour of smaller fish require further research. Future research under controlled conditions is required to document effects of external radio tagging, including fouling, injury, and to better understand long-term effects on reproduction, survival and health. We recommend that studies using external radio tags in African freshwater rivers should consider tagging effects in their methodology, monitoring and sampling design, and address practices used to minimise the impact of external radio tags on fishes.

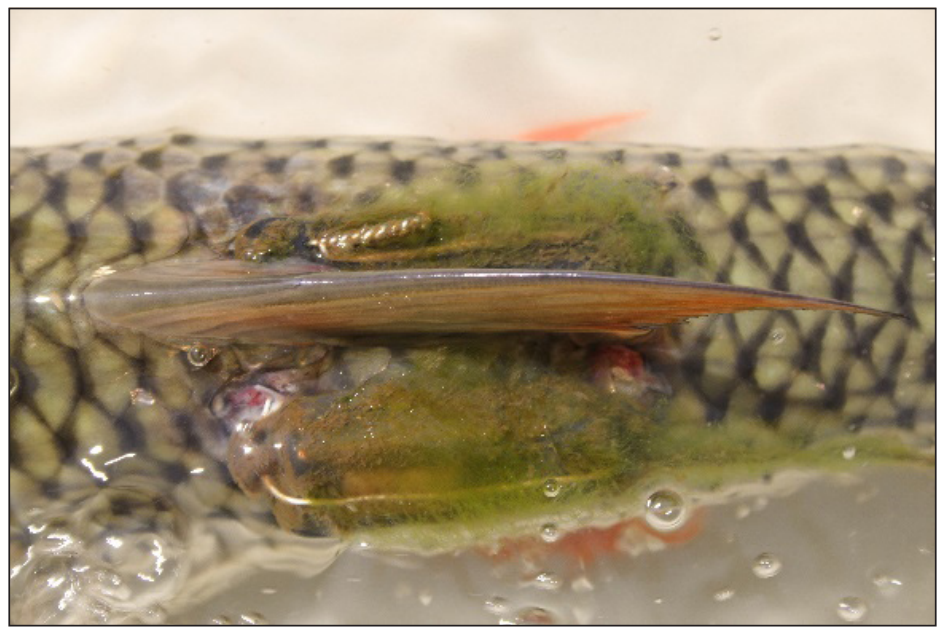

Figure 1. Fouling by green algae observed on the externally attached radio transmitter, antenna, attachment wire and plastic back-plate on tigerfish recaptured 49 days after tagging in the Kavango River, Namibia

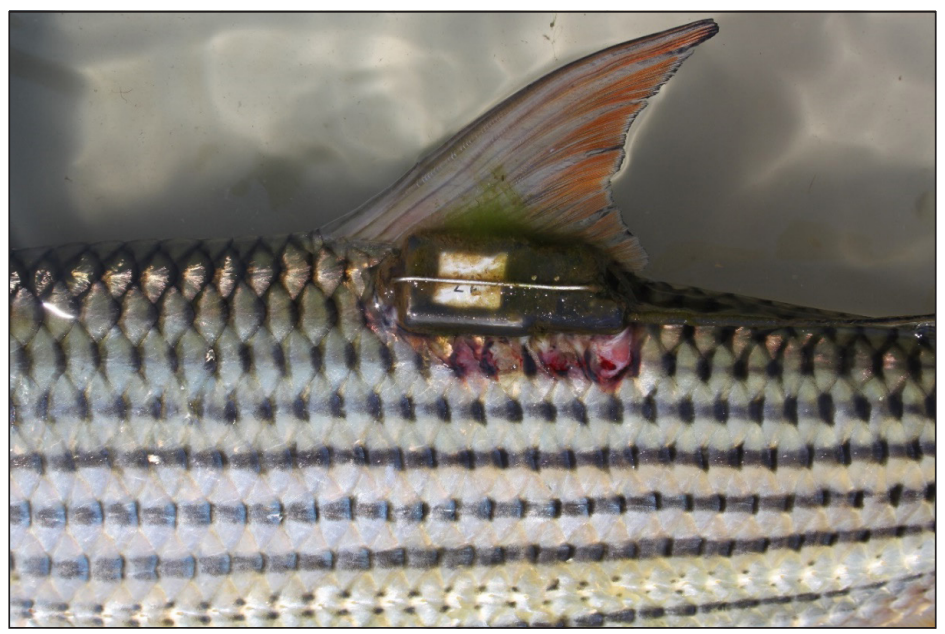

Figure 2. Visible dermal irritation approximately one scale row below the position of the externally attached radio transmitters which was probably caused by movement of the transmitter on a tigerfish recaptured 49 days after tagging in the Kavango River, Namibia. The green algae had to be removed from the transmitter to reveal the tag number 


\section{ETHICS APPROVAL}

This research was authorized by the Namibian Government under the Ministry of Fisheries and Marine Resources (Inland Fisheries Resources Act 1 of 2003 ref/INTERNAL/21MAY2017) to provide for the conservation and protection of aquatic ecosystems and the sustainable development of inland fisheries resources, to provide for the control and regulation of inland fishing; and to provide for related matters.

\section{CONFLICT OF INTEREST}

The authors declare no competing financial interests.

\section{FUNDING}

This research was funded by the Ministry of Fisheries and Marine Resources of Namibia, the Norwegian Institute for Nature Research. Partial funding was provided by the Namibia Nature Foundation (EU Community Conservation Fisheries in KAZA) and National Research Foundation (NRF) - South African Research Chairs Initiative of the Department of Science and Innovation (DSI) (Grant No. 110507).

\section{AUTHOR CONTRIBUTIONS}

FJJ conceived the paper with, OLW, EMU, CH, and TFN. FJJ collected and analysed data, and wrote the paper. OLW, EMU, $\mathrm{CH}$, and TFN contributed valuable comments to the manuscript.

\section{ACKNOWLEDGEMENTS}

The authors acknowledge the Ministry of Fisheries and Marine Resources of Namibia, and especially the staff from the Kamutjonga Inland Fisheries Institute who participated in this study. This research was funded by the Ministry of Fisheries and Marine Resources of Namibia, the Norwegian Institute for Nature Research. Partial funding was provided by the Namibia Nature Foundation (EU Community Conservation Fisheries in KAZA) and National Research Foundation (NRF) - South African Research Chairs Initiative of the Department of Science and Innovation (DSI) (Grant No. 110507). We thank anglers, including Greg Thompson from Kubu Queen Houseboats, Johan Burger, Renier Burger, Naas Jacobs, Gerhard Jacobs and Leon Krauze for their time and effort in catching tigerfish.

\section{REFERENCES}

BALMER BC, WELLS RS, SCHWACKE LH, ROWLES TK, HUNTER C, ZOLMAN ES, TOWNSEND FI, DANIELSON B, WESTGATE AJ and MCLELLAN WA (2011) Evaluation of a single-pin, satellitelinked transmitter deployed on bottlenose dolphins (Tursiops truncatus) along the coast of Georgia, USA. Aquat. Mammals. 37 (2) 187-192. https://doi.org/10.1578/AM.37.2.2011.187

BARAS E, TOGOLA B, SICARD B and BÉNECH V (2002) Behaviour of tigerfish Hydrocynus brevis in the River Niger, Mali, as revealed by simultaneous telemetry of activity and swimming depth. Hydrobiologia. 483 (1) 103-110. https://doi.org/10.1007/978-94-017-0771-8_12

BURNETT M, O'BRIEN G, WEPENER V and PIENAAR D (2018) The spatial ecology of adult Labeobarbus marequensis and their response to flow and habitat variability in the Crocodile River, Kruger National Park. Afr. J. Aquat. Sci. 43 (4) 375-384. https://doi.org/10 2989/16085914.2018.1517077

BURNETT M J, O'BRIEN GC, JACOBS FJ, BOTHA F, JEWITT G and DOWNS CT (2020) The southern African inland fish tracking programme (FISHTRAC): An evaluation of the approach for monitoring ecological consequences of multiple water resource stressors, remotely and in real-time. Ecol. Indic. 111 106001. https:// doi.org/10.1016/j.ecolind.2019.106001

COUNIHAN TD and FROST CN (1999) Influence of externally attached transmitters on the swimming performance of juvenile white sturgeon. Trans. Am. Fish. Soc. 128 (5) 965-970. https://doi. org/10.1577/1548-8659(1999)128<0965:IOEATO >2.0.CO;2
CROOK DA (2004) A method for externally attaching radio transmitters to minimize dermal irritation. J. Fish Biol. 64 (1) 258-261. https:// doi.org/10.1111/j.1095-8649.2004.00282.x

HERKE SW and MORING JR (1999) "Soft" harness for external attachment of large radio transmitters to northern pike (Esox lucius). Fish. Res. 39 (3) 305-312. https://doi.org/10.1016/S01657836(98)00197-0

JACOBS F, O'BRIEN G and SMIT N (2016) Diel movement of smallmouth yellowfish Labeobarbus aeneus in the Vaal River, South Africa. Afr. J. Aquat. Sci. 41 (1) 1-4. http://doi.org/10.2989/1608591 4.2015.1136804

JACOBS FJ, NAESJE TF, ULVAN EM, WEYL OL, TIYEHO D, HAY CJ, O'BRIEN GC, and DOWNS CT (2020) Implications of the movement behaviour of African tigerfish Hydrocynus vittatus for the design of freshwater protected areas. J. Fish Biol. 96 (5) 1260 1268. https://doi.org/10.1111/jfb.14158

JEPSEN N, THORSTAD EB, HAVN T and LUCAS MC (2015) The use of external electronic tags on fish: an evaluation of tag retention and tagging effects. Anim. Biotelem. 3 (49) 1-23. https://doi.org/10.1186/ s40317-015-0086-z

MCCLEAVE JD and STRED KA (1975) Effect of dummy telemetry transmitters on stamina of Atlantic salmon (Salmo salar) smolts. J. Fish. Board Can. 32 (4) 559-563. https://doi.org/10.1139/f75-071

MELLAS EJ AND HAYNES JM (1985) Swimming performance and behavior of rainbow trout (Salmo gairdneri) and white perch (Morone americana): effects of attaching telemetry transmitters. Can. J. Fish. Aquat. Sci. 42 (3) 488-493. https://doi.org/10.1139/f85-066

MOORE A, RUSSELL IC and POTTER ECE (1990) The effects of intraperitoneally implanted dummy acoustic transmitters on the behaviour and physiology of juvenile Atlantic salmon, Salmo salar L. J. Fish Biol. 37 (5) 713-721. https://doi.org/10.1111/j.1095-8649.1990. tb02535.x

O'BRIEN G, BULFIN J, HUSTED A and SMIT N (2012) Comparative behavioural assessment of an established and a new tigerfish Hydrocynus vittatus population in two man-made lakes in the Limpopo River catchment, southern Africa. Afr. J. Aquat. Sci. 37 (3) 253-263. https://doi.org/10.2989/16085914.2012.723196

O'BRIEN GC, JACOBS F, CRONJE L, WEPENER V and SMIT NJ (2013) Habitat preferences and movement of adult yellowfishes in the Vaal River, South Africa. S. Afr. J. Sci. 109 1-8. http://doi.org/10.1590/ sajs.2013/20120095

ØKLAND F, HAY C, NAESJE T, NICKANDOR N and THORSTAD E (2003) Learning from unsuccessful radio tagging of common carp in a Namibian reservoir. J. Fish Biol. 62 (3) 735-739. https://doi. org/10.1046/j.1095-8649.2003.00043.x

ØKLAND F, THORSTAD E, HAY C, NÆSJE T and CHANDA B (2005) Patterns of movement and habitat use by tigerfish (Hydrocynus vittatus) in the Upper Zambezi River (Namibia). Ecol. Freshwater Fish. 14 (1) 79-86. https://doi.org/10.1111/j.1600-0633.2004.00080.x

ROUX F, STEYN G, HAY C and WAGENAAR I (2018) Movement patterns and home range size of tigerfish (Hydrocynus vittatus) in the Incomati River system, South Africa. Koedoe. 60 (1) 1-13. https://doi.org/10.4102/koedoe.v60i1.1397

THORSTAD E, ØKLAND F and FINSTAD B (2000) Effects of telemetry transmitters on swimming performance of adult Atlantic salmon. J. Fish Biol. 57 (2) 531-535. https://doi.org/10.1006/jfbi.2000.1315

THORSTAD E, ØKLAND F and HEGGBERGET T (2001) Are long term negative effects from external tags underestimated? Fouling of an externally attached telemetry transmitter. J. Fish Biol. 59 (4) 1092-1094. https://doi.org/10.1006/jfbi.2001.1688

THORSTAD EB, HAY CJ, NÆSJE TF, CHANDA B and ØKLAND F (2005) Movements and habitat utilization of nembwe, Serranochromis robustus (Günther, 1864), in the Upper Zambezi River. Afr. Zool. 40 (2) 253-259. https://doi.org/10.1080/15627020.2005.11407324

THORSTAD EB, RIKARDSEN AH, ALP A and ØKLAND F (2013) The use of electronic tags in fish research: an overview of fish telemetry methods. Turk. J. Fish. Aquat. Sci. 13 881-896. https://doi. org/10.4194/1303-2712-v13_5_13

WINTER J, MURPHY B and WILLIS D (1996) Advances in underwater biotelemetry. In: Murphy BR and Willis DW (eds). Fisheries Techniques ( $2^{\text {nd }}$ edn.) American Fisheries Society, Bethesda, Maryland. 